\title{
Women's Empowerment Campaigns: Helpful or Harmful to the Workplace?
}

\author{
C. W. Von Bergen \\ Southeastern Oklahoma State University \\ Martin S. Bressler \\ Southeastern Oklahoma State University
}

Women's empowerment campaigns create greater equality for women in numerous areas including social, political, economic, and occupational fields. However, the current \#MeToo and Time's Up movements have become increasingly hostile toward men. This hostility has developed an anti-male environment that may be perceived by men as unfair restrictions on their behavior and boundaries on their autonomy. This leads to adoption of behavior and attitudes opposite of the intended effects and that may do more harm than good. This response is explained as psychological reactance. The authors discuss its harmful impact in the workplace offer suggestions for mitigating these situations.

Keywords: Women's Empowerment, Reactance, Boomerang Effect, Forbidden Fruit Effect

\section{INTRODUCTION}

'Adam was but human - this explains it all. He did not want the apple for the apple's sake, he wanted it only because it was forbidden.'

\section{Mark Twain, Pudd'nhead Wilson}

Mark Twain's passage above is based on the Biblical book of Genesis. According to the Bible, Adam and Eve had an abundance of food in the Garden of Eden but they could not resist the fruit of one tree that they were forbidden to eat. This scenario refers to indulgence or pleasure that is thought to be illicit in some way and is consistent with the idea that anything prohibited or restricted becomes even more attractive and desirable. There is something in human nature that wants what it cannot have. Twain understood this, and behavioral science researchers likewise recognize this experience and have termed it psychological reactance.

In this paper, we discuss how women's empowerment campaigns, which at their core are about equality of men and women in terms of rights and opportunities, have become more vicious in their depiction of males in their attempt to achieve gender parity. Their messages have increasingly been associated with strong, forceful, and angry language (Chemaly, 2018; Cooper, 2018; Traister, 2018). These characterizations may stimulate psychological reactance in men, which may do more harm to women than good. We begin by discussing some facets of the women's rights movement, then examine psychological reactance and related concepts followed by its implications in the workplace. We then offer 
several methods social justice warriors can employ to reduce the harmful effects of male reactance and thereby advance the cause of gender equity and conclude with a summary.

\section{DISCUSSION}

\section{Some Features of Women's Rights Movements}

The great abolitionist, Frederick Douglass, said that individuals must fight to succeed, and that agitation comes with progress: "If there is no struggle, there is no progress... Power concedes nothing without a demand" (1857/1950, p. 436). Douglass believed that progress starts with the desire for something of exceptional value, and the willingness to endure work, suffering, and sacrifice to get it. Over the last several decades, it seems that women's empowerment movements have followed Douglass's maxim. Ongoing struggles manifested in these campaigns for gender equality today include ensuring equal economic opportunities, educational equity, ending gender-based violence, rape, and sexual harassment, and systemic reform in institutions that perpetuate discrimination against women. 2018 will be remembered as the year that an almost-countless number of prominent men from different fields saw their careers damaged, if not destroyed (e.g., Matt Lauer, Louis CK, Harvey Weinstein, Bill Cosby, Les Moonves, Senator Al Franken). It was the year of \#MeToo and Time's Up movements.

As New York Senator Kirsten Gillibrand, founder of Off the Sidelines (n. d.), a political action committee created to get more women involved in public life, indicated, "... more and more women are feeling emboldened to raise their voices and fight for the issues that matter most to them, from sexual harassment in the workplace to paid leave" (Schnall, 2017). Women are increasingly protesting, marching, mobilizing, organizing, revolting, tweeting, posting, texting, running for office, and demanding changes to achieve equity in social, political, employment, and economic matters. Women seem more engaged, energized, and resolute than ever and in the process, there appear attempts by both men and women to devalue men. In attempts to lift females, society has diminished males (Rosin, 2012).

These movements which began as pro-female years ago have become increasingly anti-male and vitriolic attacks toward males are frequent today as evidenced by such comments (by both men and women) as: "Boys are broken..." (Black, 2018), "men need deprogramming” (Haglage, 2019), “... masculinity is fundamentally toxic" (Goodwin, 2018), "Men, who needs them? Don't need to be alive anymore for the world to continue" (Kohn, 2016), and "Men have made a mess of society" (Tudor, 2015). Iceland elected a woman prime minister, Johanna Sigurdardottir, who vowed to end the "age of testosterone" (Akbar, 2012). "What do you call a man with half a brain? Gifted."

Moreover, one joke book is titled Men and Other Reptiles (Contemporary Books, 1993) and another is 101 Reasons Why a Cat Is Better Than a Man (Zobel-Nolan \& Hollander, 1994). New York Times columnist Maureen Dowd received criticism from a range of people, men and women alike, with her controversial book asking rhetorically Are Men Necessary? (2006) and Rosin (2012) penned a book The End of Men: And the Rise of Women. McGee and Hantla (2013) reviewed the portrayal of fathers in popular media and noted that dads are increasingly depicted as buffoonish, ignorant, self-centered, and inept. At best, television dads are nominal or figurehead leaders of the home, but at worst, "they are relegated to the intellectual level of the family pet" (McGee \& Hantla, 2013, p. 36). Shows such as Father Knows Best, Leave It to Beaver, or Good Times were replaced by Married with Children, Roseanne, and The Simpsons. Silly Dads have replaced by Wise Fathers.

While public criticism of women is taboo, public denigration of men is a major industry. Malebashing is entertaining, lucrative, and can earn its practitioners millions of followers on social media (Medinger, 2018). Even the American Psychological Association has gotten in on the act and wants to help boys and men because it says that traditional masculinity is psychologically harmful (Pappas, 2019).

The consequences of such male devaluing seem likely to have a negative impact on both sexes: selfloathing and/or a resistance-generated misogyny among men, and contempt for men and misandry among women.

The dominant narrative of masculinity voiced today is that men are strongly prejudiced against women, entitled, corrupt, damaged, malevolent, dysfunctional, and unskilled when it comes to 
relationships and dealing with their emotions. Goodwin (2018) indicated that it is difficult to determine any constructive role for men, beyond apologetic re-tweeters of feminist memes. A male cannot express an opinion that is contrary to this pervasive narrative without being labeled a bigot or xenophobe. And even when they are not challenging women's rights, men's opinions are worthless because they are considered oppressors.

Such attacks, however, may have unexpected adverse effects for women (Ortiz, 2018; Parker, 2018; Thompson, 2018). Rather than assisting women in achieving equality in numerous areas, current women's empowerment campaigns that devalue males may result in unintended deleterious consequences for females. This is explained in terms of psychological reactance and related concepts such as the boomerang and forbidden fruit effects which are discussed below.

\section{Psychological Reactance, the Boomerang Effect, and Forbidden Fruit Effect}

Reactance is aroused in individuals when their real or perceived freedom to choose or act is threatened, reduced, or eliminated (Brehm, 1966). It has both underlying emotional and cognitive components (Rains, 2013). Anger is the predominant emotional response and counter-argumentation (i.e., negative thoughts or critiques of the message) is the cognitive response underlying reactance. This state is driven by people's fundamental desire for self-determination in their environment and a strong preference to see themselves as "masters of their own fate" (Burgoon et al., 2002, p. 216).

Push hard enough against peoples' freedoms and they will push back. The idea that for every action, there is an equal and opposite reaction has been termed reactance in the psychological literature (Edwards, Li, \& Lee, 2002). Researchers assert that reactance is plausibly viewed as an individual adverse reaction, an anti-conformity (Grabitz-Gniech, 1971), a counter-argumentation (Rains, 2013), and a motivation for message rejection (Clee \& Wicklund, 1980) involving a combination of affect, particularly anger and unfavorable cognitions toward provocative communicators and their messages (Rains \& Turner, 2007).

Reactance is an unpleasant state that consists of pressures to re-establish the threatened or lost freedom. Freedoms can be understood as specific beliefs about what a person can and cannot do (Miron \& Brehm, 2006). According to reactance theory persons possess behavioral freedoms that are established by past and/or present behavior as well as by expectations about future behavior (Rosenberg \& Siegel, 2018). Anything that impedes (e.g., attempted social influence; Brehm, 1966) or completely blocks (e.g., outright bans; Mazis, Settle, \& Leslie, 1973) people from performing a behavior or holding a certain position can be a threat to freedom that often leads to reactance. People may even interpret acts that are typically beneficial as threats to their freedom to act as they choose. For instance, Krishnan and Carment (1979) found that having a confederate help a participant on a task pressured them to return the favor, which aroused reactance by threatening their freedom to help or not (for similar results see Nemeth, 1970).

Feelings of impaired autonomy trigger reactance because of perceived unfair restrictions on their actions. The key term here is, 'unfair.' People can accept restrictions, but they must feel that restrictions are reasonable, equal, and just. Psychological reactance emerges in children at about 2 two years of age (remember the so-called terrible twos?) perhaps because children at this age first come to a recognition that they are individuals and no longer do they view themselves as mere extensions of the social milieu, but rather as identifiable, singular, and separate beings (Levine, 1983).

Reactance is said to arise in response to the environment and used to help persons reestablish freedom and control of a situation. Shakespearean characters Romeo and Juliet Capulet were the young couple whose love was doomed because of the feud between their families. Despite the parents attempts to keep them at a distance, the lovers found lasting union in their suicide - an ultimate assertion of free will in response to family restrictions. On the contrary, in the musical The Fantasticks, neighboring fathers build a fence between their properties to make the daughter of one of them and the son of the other fall in love with each other. The children saw the fence as an encroachment on their freedom to be together, and as can be predicted by reactance theory, the young couple fell in love.

Research shows that people do not merely ignore freedom-limiting messages, but rather act against them, generating backlash effects in a number of different areas (Mann \& Ward, 2001). For example, 
individuals provided with a recommendation against an option not only failed to decrease choice of that option but instead increased the choice of it (Fitzsimons \& Lehmann, 2004). In one study, participants rated a record as much more desirable if they learned that they could not choose to receive it as a gift and had to choose a different record instead (Brehm, Stires, Sensenig, \& Shaban, 1966). In another study, Mazis et al. (1973) assessed the attitudinal effects of a municipal ban of phosphate-based laundry detergents in Miami, Florida. By conducting a survey study, they found that inhabitants of Miami were significantly more positive towards phosphate-based laundry detergents than inhabitants in Tampa, Florida - a municipality that had not enacted any ban on phosphate-based detergents (control group).

Two outcomes related to reactance are the boomerang effect and the forbidden fruit effect. One method of restoring one's threatened freedom may involve embracing the derogated attitude or performing unsanctioned behavior (Brehm, 1966). This has been termed a "boomerang effect" (Brehm \& Sensenig, 1966) whereby the perceived coercion is met with an opposite but equal influence, which is used by people to reinstate their autonomy and freedom of choice. When such influence attempts are perceived as prohibitions or censorship, the forbidden fruit theory holds that people find things more desirable and therefore more inclined to engage in those taboo activities (DeWall, Maner, Deckman, \& Rouby, 2011).

Reactance leads to individuals devaluing the actions being promoted, increasing their effect toward the actions being discouraged, refusing to submit to pressure, or expressing aggression or hostility toward the source of the message (Wicklund, 1974). Over decades of research, reactance effects have been found in conjunction with efforts to pursue normatively positive outcomes such as preventing smoking or drug use (Wolburg, 2006), limiting alcohol intake or television viewing (Dillard \& Shen, 2005), a boomerang effect in one's position on an issue (Worchel \& Brehm, 1970), denial of the threat (Worchel, Andreoli, \& Archer, 1976), and reducing littering and pollution (Mann \& Hill, 1984). We now discuss several factors associated with reactance.

\section{Group Reactance}

While the discussion of reactance has historically focused on individual responses, there is also evidence for group reactance when a group's freedom is threatened in some way. Worchel (2004) provided some initial evidence for the existence of group reactance. He told a group of participants they would be able to decide the seating arrangement in an experiment. Then, reneging on this promise, they were told how to arrange their chairs. Members of the group reacted with anger. In this case, the denial of freedom motivated behavior to regain their group freedoms. In a situation threatening to their social identity, people may consider the interests of their group. This may be because group interests overlap with personal interests, but also when the group identity is an important part of the self (i.e., high identifiers).

Such group reactance may be an important motivational state that encourages group resistance, understood as behavioral or psychological tendencies to defend the interests of the group. Threats to freedom of self raise the issue of how the self is conceptualized, and this can include the group self outlined in social identity and self-categorization theory (Turner, Hogg, Oakes, Reicher, \& Wetherell, 1987). Thus, threats to individual freedom can be broadened to include threats to group identity and its associated values and norms.

Relatedly, Miron and Brehm (2006) indicated that group categorization could threaten people's freedom to identify or behave as they please. Indeed, even positive categorizations (e.g., "mother," p. 9) can induce reactance if people feel a stereotype limits their behavioral freedom in a way that is important to them. This suggestion aligns with early research by Wicklund (1974), which indicated discrimination would cause reactance. More recent evidence in support of this idea comes from Kray, Thompson, and Galinsky (2001), who found that threats to people's freedom to identify with the group of their choosing can lead to the experience of reactance. In part, this may result from vicarious reactance. 


\section{Vicarious Reactance}

Individuals can experience reactance themselves but also while observing a threat to another person's freedom (Andreoli, Worchel, \& Folger, 1974). In their study, the authors found that "reactance can be aroused by the mere observance of a threat to another's freedom, without the perception of one's own freedom being potentially directly threatened" (p. 767). Sittenthaler, Jonas, and Traut-Mattausch (2016) assessed the subjective experience of vicarious reactance and found that people experienced strong reactance even if they merely observed or read about a freedom threat to another person.

Perhaps vicarious reactance may account for former U.S. President Bill Clinton's popularity with voters as measured by job approval evaluations which reached its highest point at $73 \%$ and an all-time high for Mr. Clinton, shortly after his impeachment proceedings (CNN.com, 1998). Such a finding could be interpreted through the lens of vicarious reactance in which U.S. voters reacted negatively to Congress's attempt to limit Mr. Clinton's freedom and autonomy by impeaching him and removing him from office by finding him and his performance as more favorable.

\section{Gender}

Men resist external influences more than women (e.g., Eagly, 1983; Maccoby, 1990). Thus, it is not surprising that research supports the notion that men are more reactant than women (Woller, Buboltz, \& Loveland, 2007).

\section{Message Language}

People in general, don't like being told how to act and what to think and therefore, may discard markedly authoritative restrictions and studies have repeatedly demonstrated that persuasive messages limiting or threatening to limit perceived freedoms or highlighting the high levels of fear if one fails to comply with the advocacy can lead to reactance, which subsequently reduces message acceptability and intentions to behave in accordance with the message (for a meta-analysis, see Rains, 2013). Direct evidence can also be in the form of a positive association between fear and the construct of psychological reactance operationalized as the combination of negative cognition and anger (e.g., Shen, 2011).

Moreover, increased levels of reactance are aroused when forceful, dogmatic, controlling, explicit (threatening), fearful, and threat-to-choice language, generally defined as the direction and degree of distance from neutrality conveyed by the message source (Bowers, 1963) are used (Dillard \& Shen, 2005). Grandpre et al. (2003) found that implicit messages were more effective than explicit ones in persuading adolescents, whether pro- or anti-smoking, noting that explicit messages elicit reactance regardless of message position. Such language constitutes a strong threat to one's need for autonomy and self-determination (Shen \& Coles, 2015). Wicklund (1974) indicated that such fear appeal messages are high-pressure social influence attempts that tend to arouse psychological reactance.

Furthermore, not only may the message content impact have unintended negative outcomes but also the number of vicious messages communicated may have counterintuitive effects. Moral outrage has traditionally served a valuable social function, expressing group values and inhibiting deviant behavior, but the exponential dynamics of Internet postings make this expression of legitimate individual outrage appear excessive and unjust. While comments against offensive behavior and injustice can be seen as legitimate and vital for social progress as individual remarks when individuals are disparaged by thousands of strangers online such behavior may be seen as bullying and lead to greater sympathy for the offender (Sawaoka \& Monin, 2018). According to co-author Monin, "People start to think, 'This is too much - that's enough.' We see outrage at the outrage" (de Witte, 2018).

\section{Interventions Designed to Change Antisocial Behaviors}

Many women's campaigns seek to combat males' hostile behavior including domestic abuse, sexual harassment, sexual and nonsexual violence, and assault (Malamuth, Huppin, \& Linz, 2018) but often generate adverse reactance in men. For example, an analysis of the consequences of a domestic violence campaign that included multiple television and newspaper advertisements demonstrated such unintended effects (Keller, Wilkinson, \& Otjen, 2010). A primary goal of the program was to change the attitudes and 
behaviors of potential perpetrators. Only women's perception of the severity of domestic violence (e.g., "Domestic violence is a serious issue that requires government or police involvement") increased after the campaign. Perceptions of the severity of domestic violence, however, substantially decreased for the men in the study.

Cardaba, Brinol, Brandle, and Ruiz-SanRoman (2016) conducted research on the effects of antiviolence campaigns in different countries with different age populations. In one study, they found that individuals with relatively higher scores in aggressiveness showed a boomerang effect of anti-violence messages since they actually increased their favorability of attitudes towards violence. In contrast, the antiviolence campaigns were effective for those with relatively lower trait aggressiveness. In the second study, the intervention campaign again worked for the low trait-aggressive individuals but not for the high trait-aggressive participants.

Lastly, in summarizing the literature on interventions on college campuses to reduce sexual violence and aggression, Malamuth et al. (2018) noted that many such programs fail with men at high risk for sexual aggression who are a key target of such interventions because such programs are likely to generate "hostility reactance" (p. 20), one of the key causes of both sexual violence itself and the unintended adverse effects of the interventions. Thus, data showing reactance effects for interventions specifically focusing on aspects of reducing male violence (Cardaba et al., 2016) as well as in various other areas, such as safe sex messages (e.g., Witte, 1992) and anti-smoking and anti-drinking campaigns (Prince, Reid, Carey, \& Neighbors, 2014) support this conclusion. It seems that there is significant evidence for reactance effects that target men's hostile behavior.

\section{Individual vs. Collectivistic Cultures}

Culture can also be a factor that impacts reactance. As members of a highly individualistic society (the U.S. is the most individualistic culture in the world; Clearly Cultural, n. d.), Americans do not like to be told what to do or how to feel. When others try to influence their behaviors or opinions, Americans often respond with psychological reactance. This tendency is so strong that when someone explicitly tries to influence their opinions in one direction, they will even change their attitudes in a direction opposite to their original feelings (Heller, Pallak, \& Picek, 1973). In summary, people with a more independent selfconstrual or an individualistic cultural background exhibit stronger reactance when restricted and that it is influenced by people's cultural self-construal.

In summary, many of these messages emanating from women's empowerment movements are directed at men for whom reactance is aroused more easily than for women and many of these communications use strong, explicit language in the hopes of changing men's antisocial behavior leading to push back from males in the form of psychological reactance and boomerang and forbidden fruit effects. Moreover, these messages are being communicated in individualistic cultures such as the U.S. where attacks against individuals are seen as particularly intolerable. Indeed, just watching the multitude of acerbic messages of rage directed at men can lead to increased levels of reactance which will often influence them to adopt positions opposite those intended by the communication. This seems to be particularly harmful in business.

\section{Implications in the Workplace}

Human history is full of unintended consequences. Much like the importation of invasive kudzu vines to America, the introduction of rabbits in Australia in 1859 for sporting purposes, and the cobra eradication drive in colonial India where the British-controlled government paid a bounty for each dead venomous snake but led instead to enterprising Indians breeding them for income, resulting in a greater number of snakes (Dubner, 2012). However, in some instances the attempted solution instead makes the

problem worse and women's empowerment campaigns may be having unexpected negative effects for women in the workplace as these movements and the rhetoric they spew forth have become increasingly hateful.

Here we discuss several workplace situations that may be problematic considering psychological reactance created in men which is preceded by a perceived threat to or elimination of freedom which 
leads to attitudinal and behavioral backlash that results in negative feelings about the message and negative perceptions of the source's credibility or attractiveness, often ignoring the message and intentionally contradicting them. Thus, prior to reactance arousal, individuals must sense pressure from an outside force or agent. When efforts are made to convince people by means of compelling threatening messages, this motivates people (e.g., males) to present arguments against the persuasive attempt (counter-arguing). This cognitive-reflective process leads to negative attitudes toward the message and messenger, lower behavioral intention to follow the aim of the message, and ways to restore perceived losses of freedom and autonomy. We now discuss several areas where reactance in males to women's rights communications may be presenting difficulties for women in the workplace.

\section{Experience of Anger}

Dillard and Shen (2005), Quick and Stephenson (2007), and Steindl, Jonas, Sittenthaler, TrautMattausch, and Greenberg (2015) noted that reactance is comprised of anger and negative emotions. Indeed, Brehm and Brehm (1981) stated that reactance "includes a strong urge to do something (toward restoring a freedom), and it may be accompanied by feelings of hostility" (p. 392). More recently, scholars have found an association between reactance and anger and that anger follows exposure to (a) an obstacle that interferes with one's goals, (b) demeaning offenses against oneself, or (c) inappropriate acts toward one's friends and family (Dillard \& Meijnders, 2002; Rhoads \& Cialdini, 2002).

Although anger in the workplace has been found to have some positive effects (e.g., problem solving, Miron-Spektor \& Rafaeli, 2009) its effects are overwhelmingly negative. It has been associated with negative reactions such as violence (Folger \& Baron, 1996), revenge-seeking (Bies \& Tripp, 1998), elevated blood pressure and job-related stress (Begley, 1994; Friedman et al., 2004), decreased cooperation (Allred, Mallozzi, Matsui, \& Raia, 1997), and lowered job satisfaction and productivity (Glomb, 2002).

Anger is gender consistent for men but not for women - that is, anger enhances masculinity for men but detracts from the femininity of women. Anger in men expresses dominance and control over the situation or environment, whereas anger in women conveys a loss of self-control (Campbell \& Muncer, 1994). As such, anger expressed by women is likely to provoke more negative emotions from others than anger expressed by men (Brescoll \& Uhlmann, 2008).

According to Kelley's (1973) attribution theory, when a behavior is unique and deviates from the norm (low consensus) observers are likely to attribute it to internal causes, while behavior consistent with the norm is attributed to the situation. Thus, female anger is likely to be attributed to the individual ("she is an angry person") while male anger is likely to be attributed to objective circumstances ("something really bad must have happened"). When anger is attributed to internal causes, the angry person is seen as the problem-increasing chances of organizational sanctions against that person while deflecting attention away from the initial anger-provoking event (Geddes \& Callister, 2007).

Brescoll and Uhlman (2008) confirmed this dynamic. They asked participants to observe an interview with angry or sad male or female candidates. They found that the anger of the male candidate was attributed to external causes, while the anger of the female candidate was attributed to her internal dispositions. Angry women were perceived as "out of control" and as less competent than women expressing no emotion. Female leaders who displayed anger were considered less effective than those who displayed no emotion. Similarly, Lewis (2000) found that male leaders who displayed anger were rated significantly more effective than male leaders who displayed sadness and as effective as those who displayed no emotion. Thus, anger expressed by males is perceived positively but anger expressed by females is seen negatively; they are viewed as relatively incompetent. Professional women may have to behave "unemotionally" (Brescoll \& Uhlmann, 2008, p. 274) so that they are regarded as rational (Albright, 2003). Alternatively, women who attributed their hostility to objective, external reasons did not suffer negative gender bias. 


\section{Gender Segregation}

Another problematic area involves the broad area of socialization and subsequent gender segregation. University of California-Los Angeles psychologist Kim Elsesser, the author of Sex and the Office (2015), sees "sex partition" as men's reaction to women's empowerment movements. Elsesser claims that because workplace friendships are so essential to career success, the female-male separation is the primary impediment preventing gender equity in the workplace. Not only does the sex divide disadvantage individual women, but firms also lose out as well because weak intra-organizational networks impair a firm's social capital development. If men begin avoiding women because of women's empowerment campaigns such as the \#MeToo movement it is hard to see how that will help the feminine cause. Foust-Cummings, Dinolfo, and Kohler (2011) mentioned that genuine relationships, especially with senior employees, often males, is a key contributor to job progression. Such associations are often referred to as sponsorships and sponsors, unlike mentors who give advice and are often officially assigned, know and respect people enough that they are willing to find opportunities for them and advocate and stand-up for them (Kennedy \& Jain-Link, 2019). Moreover, Elsesser (2015) emphasized that a heightened awareness of sexual harassment contributes to this partition that hinders cross-gender friendships. Bans on workplace romance along with increased awareness of sexual harassment issues have resulted in some employees becoming confused about how to interact with coworkers of the opposite sex. Instead, many employees find it easier to limit socializing to same sex coworkers. Suffice it to say, this side-effect will not serve women well in the long run. Indeed, it seems obvious that they will suffer. In part, they will be hurt because of the underlying principles of psychological reactance and the boomerang effect.

This partition limits the friends everyone has at work and research plainly shows that better networks result in faster promotions and larger paychecks (Podolny \& Baron, 1997). This is more of a women's issue since the most valuable friends are males because they typically manage most firms and are in higher executive positions. As of the 2018 Fortune list, only 24 women (4.8\%) were CEOs of Fortune 500 companies (Catalyst, 2018). Because of the sex partition, many senior male executives hesitate to have a one-on-one meeting with a lower-ranking female at work. The men are worried that a comment will be misinterpreted as sexual harassment or that their friendliness will be mistaken for romantic attention. Because of this, many male executives preferring to associate with other men, especially when it comes to dinners, drinks, late-night meetings, or business trips. The result is when it is time for promotions or pay raises, these executives are more likely to show preference to other men.

According to one report, Wall Street "risks becoming more of a boy's club, rather than less of one" (Tan \& Porzecanski, 2018) in the \#MeToo era. The article focused on the various ways some senior executives in finance have been alarmed by \#MeToo. When on business trips some male executives stay on different hotel floors from women, avoid dining alone with any woman age 35 or younger, leave the office door open during discussions with a lower-ranking female, choose not to sit next to women on flights, and avoid one-on-one meetings. Some are even invoking the "Pence Rule," after U.S. Vice President Mike Pence who has said he avoids dining alone with any woman other than his wife (Levin, 2018).

The overarching impact can be, regrettably, gender segregation. Tippett (2018) also suggests that such movements are likely to produce avoidance behaviors that discriminate against women. A manager may decide that the best way to avoid inadvertently violating a harassment policy is to a evade contact with those who might accuse them of harassment. For example, a supervisor might exclude female subordinates from business lunches, networking events, or client meetings which, in turn, limits the employee's chance for advancement because the supervisor is less familiar with her skill and potential and she receives less coaching and advice.

One wealth adviser said, simply hiring a woman has become 'an unknown risk.' Many men are so threatened by the \#MeToo movement and the plausibility that they, too, could be ruined based on a single woman's misinterpretation of an innocent gesture that they are essentially shutting down and stepping away. Michelle Lee Flores, a partner in the employment law firm at Akerman in Los Angeles, noted "... 
I've heard male executives express a real concern that having female colleagues 'could come back to bite me"' (Fisher, 2018).

Research from the Society for Human Resource Management (SHRM, 2018) suggests that Flores may be correct. In the SHRM survey of 18,000 U.S. employees, at all levels across 15 industries, about one-third (32\%) of executives say they have "changed their behavior" in the past year because of a greater awareness of the hazards of sexual misconduct at work, including risks to morale (23\%) and employee engagement (also 23\%). Only 21\% said harassment "has never been an issue" in their companies. Some measures managers told SHRM they have taken include male mentors can no longer be assigned to women less senior than themselves. Additionally, working in the office after hours is no longer allowed "for groups of fewer than three employees and must include a manager." No touching ever, and "asking permission to enter a 3-foot space, and NEVER [caps theirs] closer than 3 feet." One manager told SHRM he is "scared to say anything" to or about women, ever. In a similar vein, Smith (2018) noted that Johnny Taylor, president of SHRM, told the Chicago Tribune, that executives tell men not to go on business trips or share rental cars with women co-workers. Rather than assisting women in achieving equality in several areas, current women's empowerment campaigns that devalue males may result in unintended negative consequences for females.

A recent Pew Research Center survey (Graf, 2018) found that the increased focus on sexual harassment and assault poses new challenges for men as they navigate their interactions with women at work. About half (51\%) say the recent developments have made it harder for men to know how to interact with women in the workplace. Only $12 \%$ say this increased focus has made it easier for men, and $36 \%$ say it has not made much difference. At the same time, Americans see little upside for women's workplace opportunities because of the increased focus on sexual harassment and assault. Just $28 \%$ say it will lead to more opportunities for women in the workplace in the long run, while a somewhat smaller share $(20 \%)$ say it will lead to fewer opportunities and $51 \%$ say it will not make much of a difference.

\section{Mentoring}

It appears that women's empowerment campaigns will necessitate that mentors have a more detailed and formalized code of conduct. In-person meetings may need to occur in visible areas where one person is theoretically unable to assault another. It may be that emails between mentor and protege will need to involve CCing another person to prevent workplace harassment. Mentors may start to only be paired with people of the same gender. Since there are fewer female executives in some industries (e.g., financial services) it may be more difficult to find appropriate mentors if senior males managers elect to opt-out of mentoring activities with women because of the fear that allegations of sexual harassment may destroy their careers. Perhaps some sort of more in-depth background check will need to be conducted. It will mean that mentors will need to be very careful in their nonverbal and verbal interactions with the protegees to avoid accusations of sexual harassment or assault. Mentoring as a development tool may decrease in frequency due to companies not wanting to deal with its complexity. Group mentoring may also become more popular, in which one mentor works with a group of 4-6 proteges at a time.

University of Toronto researchers, Soklaridis et al. (2018), commented that men in academic medicine are using the \#MeToo movement to justify avoiding mentorship of women, depriving the women of key opportunities to advance their careers. The authors argue that when women started to outnumber men in Canadian medical schools, some leaders in the field raised concerns about the "feminization of medicine," even proposing that affirmative action initiatives for men might be required to close that gender gap in enrolment. Of concern to the authors is a lack of mentoring opportunities for women in academic medicine relative to men, in part because men claim that they fear false claims of sexual misconduct. The authors cite several recent studies showing that some American colleagues have stopped meeting with female colleagues or subordinates alone due to fears of false sexual harassment reports. The authors argue that mentorship is essential for career advancement in any field, including academic medicine. Nevertheless, women report less access to mentors than their male colleagues. According to Zahn, one of the authors in the University of Toronto paper, "Over and over again, I've seen women without strong mentorship choose a pathway different than that they may have preferred" 
(University of Toronto, 2018). Relatedly, Epstein, Saute, Oglensky, and Gever (1995) found that the enforcement of sexual harassment law discourages men from mentoring female colleagues.

\section{Sexual Harassment Training}

The courts classify sexual harassment as a form of sex discrimination that violates U.S. Title VII of the Civil Rights Act of 1964. With respect to the effect of sexual harassment law on employment practices, over 90 percent of large employing organizations have adopted a sexual harassment policy (Dobbin \& Kelly, 2007) and most have departments and procedures for handling sexual harassment incidents (Edelman, Uggen, \& Erlanger, 1999). Moreover, employer-provided sexual harassment training is ubiquitous in the American workplace (Perry, Kulik, Bustamante, \& Golom, 2010) and is expected to increase after media coverage of the \#MeToo and Time's Up movements. Moreover, it is becoming increasingly common in many other countries because of international regulatory developments (e.g., Ali \& Kramer, 2015). Some commentators characterize sexual harassment training as largely a symbolic effort by employers to insulate themselves from legal liability by showing that it exercised reasonable care to prevent harassment by offering such programs, but often warning of a potential "backlash" among male employees (Tinkler, 2012).

For example, Bingham and Scherer (2001) evaluated a 30-minute anti-harassment college training program consisting of three components: a 3-minute videotaped speech by the chancellor; a hand-out and oral presentation by mixed-sex, two-person teams of the university staff and faculty; and a 5-minute discussion focused on sensitizing attendees to sexual harassment. Results indicated that participants showed more knowledge about sexual harassment than did nonparticipants and were more likely to say that sexual behavior at work was wrong. Men had more favorable attitudes toward sexual behavior at work than did women but unfortunately, male participants who completed the training were significantly less likely to view coercion of a subordinate or a student as sexual harassment than were nonparticipating males or females, less willing to report sexual harassment, and more likely to blame the victim.

Other investigations indicate that participants who come into the training with more of a tendency to harass showed greater acceptance of harassment after the program (Robb \& Doverspike, 2001), and for those males with gender role conflicts (based on questionnaires completed prior to the instruction) education efforts reinforced their tolerant attitudes toward harassment (Kearney, Rochlen, \& King, 2004). Similar negative reactions to training were reported by Feldblum and Lipnic (2016) in their report to the Equal Employment Opportunity Commission.

Moreover, in their review of sexual harassment training effectiveness, Roehling and Huang (2018) reported that longer training programs, training programs that employ multiple educational methods (such as didactic, role-play, and video), and organizational support of enforcement of sexual harassment policies all led to improved knowledge and internal reporting behavior. Unfortunately, attitudes toward sexual harassment and sexual harassment incidence seem to be unaffected by these pieces of training. It is likely that reactance is at play in such training.

\section{Women's Health Care}

One unintended consequence of women's empowerment campaigns is that such movements could kill women. Preliminary research by Dr. Sarah Perman of the University of Colorado School of Medicine found that some bystanders may avoid performing CPR on women because they fear hurting them, or even being accused of sexual assault (American Heart Association, 2018). Respondents expressed concern that touching a woman's chest could be construed as assault or unwanted sexual touching. "Men don't want to appear grabby or awkward placing their hands on a woman's breast they don't know," one response read. Another said, "men are likely afraid of getting accused of some kind of sexual molestation of some sort" (Hsieh, 2018). In a related study, Dr. Marion Leary (American Heart Association, 2018) found that in a virtual reality study that participants performed less CPR or used an automatic external defibrillator less frequently for a female simulated stranger undergoing unexpected cardiac arrest than for a similar virtual male. "Worries about accusations of sexual assault or inappropriate touching were cited 
twice as many times by men as by women, while more women mentioned fear of causing injury (American Heart Association, 2018).

\section{Other Problematic Areas}

With respect to the effect of sexual harassment law on employment practices, over 90 percent of large employing organizations have adopted a sexual harassment policy (Dobbin \& Kelly, 2007) and most have departments and procedures for handling sexual harassment incidents (Edelman, Uggen, \& Erlanger, 1999). Sexual harassment laws often produce effects counter to their equalizing aims (Schultz, 2003). In addition, studies have found evidence of resistance and backlash to workplace sexual harassment policies (Tinkler, 2008). As indicated above, numerous studies have shown the undesirable effects of psychological reactance. Thus, it would seem appropriate to consider ways to mitigate reactance to preclude its adverse consequences.

\section{Mitigating Reactance}

The overall goal of women's empowerment campaigns is to inject democracy into the workplace by pushing employers toward transparency and accountability. Informed by psychological reactance theory, this paper presents systematic evidence that there can be unfavorable consequences because commentators associated with women's empowerment campaigns are pushing too hard. This is likely to enact reactance with its many negative consequences which may harm women more than helping them. Even though the sources of proscriptive messages may have good intentions, the individuals whose freedoms are being threatened or removed are unlikely to see it that way. Therefore, we now discuss several strategies for re-establishing individuals' (primarily men) sense of autonomy which involves diminishing reactance and the restoration of freedom.

Clearly, reactance is maladaptive in the context of female empowerment campaigns designed to promote prosocial behaviors and it must be decreased. Preventing or mitigating reactance, operationalized as the latent combination of anger and negative cognitions (Rains, 2013), then, is about minimizing perceptions of freedom threats which serve as the motivational catalyst for resistance to another party's persuasive intent (Richards, Banas, \& Magid, 2017). Threats to perceived freedoms, which are at the root of psychological reactance, inspires individuals to put up their guard against message advocacy after recognizing that they are the unwilling targets of influence. Indeed, Brehm (1966) theorized that a message target's "perception that the communicator is attempting to influence will tend to be seen as a threat to one's freedom to decide for oneself" (p. 94), which manifests in reactance-induced resistance to persuasive appeals. Several approaches have been found to be effective in reducing reactance and its harmful effects which are presented below: 1) language intensity, 2) choice-enhancing postscripts, 3) empathy, and 4) narrative.

\section{Language Intensity}

The destructive effects of psychological reactance may be neutralized or eliminated through strategies designed to restore perceptions of freedom. First, numerous studies have convincingly demonstrated the connection between language intensity and increased reactance (e.g., Quick \& Considine, 2008). Language intensity results in reactance when messages employ commanding and/or explicit speech, directly communicating the source's intentions using such modal verbs as should, ought, and must. High controlling language is often characterized by the use of imperatives as opposed to propositions or indirect suggestions. It uses opinionated language which may sometimes be described by absolute allegations (e.g., "It cannot be denied ..." or "There is no doubt whatsoever...") and/or derision aimed at the receiver's perspective (e.g., "Any fool can see that ..." or "You can't possibly be serious ..."). Such opinionated speech signals what communicators think about a topic in a domineering way and what they think about anyone who might disagree with their position on the matter, thereby closing down any debate (Miller, 2015). Low controlling messages use less forceful and politer tones. Such autonomysupportive language implicitly emphasizes self-initiation and choice and tends to be less detailed, less precise, and often includes the use qualifiers such as "perhaps", "possibly", and "maybe" (Vansteenkiste, 
Lens, \& Deci, 2006). Hence, appeals to influence male behavior in women's empowerment campaigns may be more effective in allaying reactance if messages are communicated with non-threatening language to reduce the degree to which message targets perceive their freedom to choose how to behave is in jeopardy.

In their classic study, Weiner and Brehm (1966) found that consumers bought more of a certain kind of bread when influenced only moderately ("please try") compared to a stronger influence ("you are going to buy"). Likewise, a stronger sign on the door of a public bathroom installed to prevent people from painting graffiti on the walls ("Do not write on these walls under no circumstances") resulted in more forbidden behavior than the weaker phrasing ("Please do not write on these walls") (Pennebaker \& Sander, 1976). Similarly, Fogarty and Youngs (2000) found that patients who were exposed to a partnership-oriented advice-giving tone (which emphasized the positive consequences of compliance) by their medical professional, as opposed to an authoritative advice-giving tone (which emphasized the negative consequences of failing to follow the doctor's instructions) were more likely to comply and less likely to experience reactance to their physician's requests. Such findings are consistent with studies demonstrating that hard-sell tactics are less persuasive than soft-sell tactics (Clee \& Wicklund, 1980) point out that hard-sell messages reveal the intent of the persuader and therefore should be met with greater resistance. Robertson and Rossiter (1974) find that perceptions of persuasion correlated with less favorable attitudes toward the product being sold and Miller (2015) found that the more clearly receivers perceive a source's intent to influence, the greater their reactance is likely to be. Additionally, when a communicator comes on too strongly, people may react with negative attitude change by moving in the direction that is the opposite of the one being advocated - even, ironically, when the speaker's position agrees with their own (Heller et al., 1973). We now present a second approach that has been found to allay psychological reactance and its damaging effects.

\section{Choice-enhancing Postscripts}

Just as domineering and controlling language induces reactance, the presence of choices tends to diminish it. Such an intervention to reduce reactance was proposed by Miller et al. (2007) in which they offered the idea of restoration postscript messages designed to remind targets of their freedom to choose after being exposed to a persuasive message. Basically, a restoration postscript tells the recipient after the persuasive message, "the choice is yours. You are free to decide for yourself" (Quick, Shen, \& Dillard, 2013, p. 177). In a very straightforward way, restoration might be accomplished by adding a choiceemphasizing postscript to the end of a persuasive message. In such a way, reactant individuals may be given a chance to restore their freedom. This method simply involves offering the individuals a choice. For example, Bessarabova, Miller, and Russell (2017) used the following high-threat message with respect to recycling followed by the restoration postscript and noted a decrease in reactance:

High-threat message: "There's really no choice when it comes to recycling. You simply have to do it!” (p. 390)

Restoration postscript: "You've probably heard a lot about recycling, even messages similar to this. Of course, you don't have listen to any of them. You know what is best for yourself. We all make our own decisions and you make your own decisions too. The choice is yours. You're free to decide for yourself." (p. 391)

Concerning health risk-related prohibitions, a postscript restoration message following a proscriptive persuasion attempt can function as an effective mechanism for undoing the detrimental effects of controlling language, reducing the level of perceived explicitness and, hence, decreasing the potential for generating the anger and negative criticism incumbent upon a reactant response. Moreover, since messages low in perceived explicitness may often be perceived as deliberately persuasive in nature, restoration postscripts can be effective in reducing reactance even when following relatively lowcontrolling, implicitly stated messages (Miller et al., 2007). With proper emphasis placed on a message receiver's ultimate choice options, it may be possible to fashion an explicit message with a restoration 
postscript to generate less reactance than an implicit message without a restoration postscript, thus allowing for clear, unambiguous, straightforward statements that nevertheless greatly reduce if not completely avoid angry, reactant responses.

\section{Empathy}

A third approach involves the inclusion of empathy in persuasive messages. Empathy can be an effective means to reduce reactance. Given that reactance can be considered as a mixture of anger and negative cognition (Dillard \& Shen, 2005), messages that inhibit unintended anger and reduce counterargument should diminish reactance as well. It has been proposed that empathy-arousing messages fall into that strategy (Shen, 2010a, 2011). Empathy during message processing is defined as a perceptionaction process that occurs when the perception of the characters' state automatically activates the recipients' vicarious experience of the characters' state, situation, and objectives. Such empathetic responses are conceptualized to have three components: perspective taking, emotional contagion, and identification (Shen, 2010b). Perspective taking means that the message recipients adopt the viewpoint of the message and its source, which means counterargument is less likely. Emotional contagion means that the recipient's emotional experiences would be comparable to those portrayed in the message, thus less unintended emotions (including anger). Identification with the persuasive message means that the recipients tend to consider the persuasive attempt as less external, which reduces perceived threat to freedom, hence mitigating psychological reactance. There has been empirical evidence that in addition to a direct impact on persuasion, state empathy indeed mitigates psychological reactance (Shen, 2010a, 2011). Campbell and Babrow (2004) also noted that empathy decreased resistance to health intervention messages. Shen $(2010 \mathrm{a}, 2011)$ also identified three message features that are believed to induce empathy: the degree to which a message portrays characters' pain and suffering, the degree to which the message is realistic, and the degree to which the message is affect-laden.

\section{Narrative}

Another approach to minimizing reactance involves a narrative. Many of the messages that have been used to study reactance consist of arguments and evidence. But research on narrative indicates that stories may also be an effective means of inducing a change in beliefs and attitudes. Moyer-Gusé (2008) observed that one of the reasons for narrative effectiveness is the inhibition of reactance. This is thought to occur to the extent that the narrative form obscures persuasive intent. Indeed, Moyer-Gusé and Nabi (2010) found that perceived persuasive intent was positively associated with reactance for individuals exposed to a dramatic narrative. Hence, individual differences in perceived persuasion intent were in evidence even though a single narrative message was presented. Those differences corresponded directly with reactance.

These alternatives are designed to minimize or remove the anger and negative cognitions stimulated by psychological reactance and restore lost or threatened freedoms. These strategies invoke the development of narratives having no controlling and threatening language which provide a restoration of freedom in the form of autonomy-supportive speech and postscripts that arouse empathy in receivers.

\section{CONCLUSION}

Well known American philanthropist, Melinda Gates, indicated: "I feel like we're at a point in time where equality just can't wait" (Repko, 2019, p. 6E). Gates feels that America has a window of opportunity that opened because of the \#MeToo movement and that women need to take advantage of that window (Gates, 2019). Such a viewpoint, however, may create for some an urgent need to address inequality and injustice of women by calling for increased rhetoric vilifying men which may engender the negative effects of psychological reactance.

Although Mark Twain (1884/1963) wrote The Adventures of Huckleberry Finn long before reactance, boomerang, and forbidden fruit effects were proposed, he understood the principles behind these theories well. In the novel, to increase attendance at a show, one of Twain's characters added the following line to 
the handbills advertising the show: 'LADIES AND CHILDREN NOT ADMITTED' (p. 178). Like the last line of this handbill, such restrictions on individuals' freedom increased their attraction to that which was regulated, restricted, or prohibited.

There is a human tendency to push back on calls for change, especially when such demands are restrictive or autonomy limiting. Reactance theory offers important lessons for communicators whose foremost priority must be to avoid doing more harm than good. An obvious implication is that negative reactance effects should be considered as one of the potential costs of launching communication campaigns (Ringold, 2002) directed at empowering women.

Cultural change should also be considered. Researchers and commentators (e.g., Campbell \& Manning, 2018; Friedersdorf, 2015; Haidt, 2017a) have noted the emergence of a victimhood culture in America which confers the highest moral status on those who are damaged, disadvantaged, and needy. These aggrieved parties are especially likely to highlight their own distress and innocence and publicize their injustices on social media which raises their own moral status as innocent injured groups and advertise their oppression and marginalization as confirmation that they deserve respect and assistance (Wayne, 2015). These sites have proliferated (Campbell \& Manning, 2014) and encourage others to submit descriptions of their own (perceived) maltreatment and to broadcast offensive conduct to others who may be unaware of such wrongdoings. They appeal for help, sympathy, and intervention to powerful third parties or administrative bodies to whom they must make the case that they have been victimized (Campbell \& Manning, 2014; DeScioli \& Kurzban, 2013). In fact, a key element of today's activism is concerned with gaining significant public support to persuade authorities to act by documenting offenses that, collectively, are more severe than any specific occurrence and to call attention to such transgressions to illustrate the presence of larger patterns and practices of inequality.

This has resulted in increased numbers and intensities of anger and outrage in women's empowerment campaigns and much communication about men these days tends to focus disproportionately on portraying them as villains and women as victims (Synnott, 2010). Such messaging could be perceived as threatening and invoking psychological reactant motivation in men which increases resistance to persuasion and is a counterforce involving the tendency to adopt a perspective contrary to what they are highly pressured to accept. Such tactics by sincere albeit somewhat naïve and ill-informed supporters may do more harm than good and may undermine women's initiatives. All should remember the words of Martin Luther King who noted: "shallow understanding from people of good will is more frustrating than absolute misunderstanding from people of ill will" (1963).

Reformers should be aware that change may be good but be wary of unintended consequences. Turning men and women into hostile opposing camps is not going to be good for anyone. The old maxim, "Sticks and stones may hurt my bones, but words can never hurt me," is incorrect. Words can and do wound. They perpetuate stereotypes that give rise to bigotry and misandry and misogyny, neither of which should be tolerated.

It does not help women to engage in the sport of putting down men. We might begin by considering the harm done by psychological reactance. It could open the door to compassion and help us build a more humane world, but not before increased disparagements. Haidt (2017b) noted that those institutions, organizations, and societies that have made significant advancement toward equality, diversity, and inclusion can expect to experience greater criticisms regarding such issues (Haidt, 2017b).

As an alternative, we call for men and women to act and treat each other professionally in the workplace. This includes maintaining a professional work environment where employees can interact without fear of sexual harassment and without fear of false accusations. In today's professional work environment, men and women should be comfortable working with one another without anger, outrage, and intimidation. 


\section{REFERENCES}

Akbar, A. (2012). The End of Men and the Rise of Women by Hanna Rosin Viking. Retrieved from https://www.independent.co.uk/arts-entertainment/books/reviews/the-end-of-men-and-the-rise-ofwomen-by-hanna-rosin-viking-8190056.html

Albright, M. (2003). Madam secretary: A memoir. New York: Miramax.

Allred, K. G., Mallozzi, J. S., Matsui, F., \& Raia, C. P. (1997). The influence of anger and compassion on negotiation performance. Organizational Behavior and Human Decision Making, 70(3), 175-187.

American Heart Association. (2018). Two Novel Studies Explore Why Women Receive Less CPR from Bystanders. Retrieved from https://newsroom.heart.org/news/two-novel-studies-explore-whywomen-receive-less-cpr-from-bystanders?preview $=$ cf16

Andreoli, V. A., Worchel, S., \& Folger, R. (1974). Implied threat to behavioral freedom. Journal of Personality and Social Psychology, 30(6), 765-771.

Begley, T. M. (1994). Expressed and suppressed anger as predictors of health complaints. Journal of Organizational Behavior, 15, 503-516.

Bies, R., \& Tripp, T. (1998). Revenge in organizations: The good, the bad, and the ugly. In R. Griffin, A. O'Leary-Kelly, \& J. Collins (Eds.), Dysfunctional behavior in organizations: Non-violent dysfunctional behavior (pp. 49-67). JAI press: Stanford, Connecticut.

Bingham, S. G., \& Scherer, L. L. (2001). The unexpected effects of a sexual harassment educational program. Journal of Applied Behavioral Science, 37, 125-153.

Black, M. I. (2018, February 21). The Boys Are Not All Right. New York Times. Retrieved from https://www.nytimes.com/2018/02/21/opinion/boys-violence-shootings-guns.html?module=inline

Bowers, J. (1963). Language intensity, social introversion and attitude change. Speech Monographs, 30, 345-352.

Brehm, J. W. (1966). A theory of psychological reactance. New York, NY: Academic Press.

Brehm, J. W., \& Brehm, S. S. (1981). Psychological reactance. New York, NY: John Wiley.

Brehm, J. W., \& Sensenig, J. (1966). Social influence as a function of attempted and implied usurpation of choice. Journal of Personality and Social Psychology, 4, 703-707.

Brehm, J. W., Stires, L. K., Sensenig, J., \& Shaban, J. (1966). The attractiveness of an eliminated choice alternative. Journal of Experimental Social Psychology, 2, 301-313.

Brescoll, V. L., \& Uhlmann, E. L. (2008). Can an angry woman get ahead? Psychological Science, 19(3), 268-274.

Buboltz, W. C., Woller, K. M. P., \& Peper, H. (1999). Holland code type and psychological reactance. Journal of Career Assessment, 7, 161-172.

Burgoon, M., Alvaro, E. M., Broneck, K., Miller, C., Grandpre, J. R., Hall, J. R., \& Frank, C. A. (2002). Using interactive media tools to test substance abuse prevention messages. In W. D. Crano.

Campbell, A., \& Muncer, S. (1994). Sex differences in aggression: Social representation and social roles. British Journal of Social Psychology, 33, 233-240.

Campbell, B., \& Manning, J. (2014). Microaggression and moral cultures. Comparative Sociology, 13(6), 692-726.

Campbell, B., \& Manning, J. (2018). The rise of victimhood culture: Microaggressions, safe spaces, and the new culture wars. New York: Palgrave Macmillan.

Campbell, R., \& Babrow, A. (2004). The role of empathy in responses to persuasive risk communication: Overcoming resistance to HIV prevention messages. Health Communication, 16, 159-182.

Cardaba, M. G., Brinol, P., Brandle, G., \& Ruiz-SanRoman, J. A. (2016). The moderating role of aggressiveness to campaigns and interventions promoting anti-violence attitudes. Aggressive Behavior, 99, 1-12.

Chartrand, T. L., Dalton, A. N., \& Fitzsimons, G. J. (2007). Nonconscious relationship reactance: When significant others prime opposing goals. Journal of Experimental Social Psychology, 43, 719-726.

Chemaly, S. (2018). Rage becomes her: The power of women's anger. New York: Atria. 
Clearly Cultural: Making Sense of Cross-Cultural Communication. (n. d.). Retrieved from http://clearlycultural.com/geert-hofstede-cultural-dimensions/individualism/

Clee, M. A., \& Wicklund, R. A. (1980). Consumer behavior and psychological reactance. Journal of Consumer Research, 6(4), 389-405.

Contemporary Books. (1993). Men and other reptiles. Chicago: Contemporary Books Publishing Group.

Cooper, B. (2018). Eloquent rage: A black feminist discovers her superpower. New York: St. Martin's Press.

de Lemus, S., Bukowski, M., Spears, R., \& Telga, M. (2015). Reactance to (or acceptance of) stereotypes: Implicit and explicit responses to group identity threat. Zeitschrift für Psychologie, 223(4), 236246.

de Witte, M. (2018). The Consequences of Viral Outrage. Retrieved from https://www.gsb.stanford.edu/insights/consequences-viral-outrage

DeScioli, P., \& Kurzban, R. (2013). A solution to the mysteries of morality. Psychological Bulletin, 139(2), 477-496.

Dillard, J. P., \& Meijnders, A. (2002). Persuasion and the structure of affect. In J. P. Dillard \& M. Pfau (Eds.), The persuasion handbook: Developments in theory and practice (pp. 309-344). Thousand Oaks, CA: Sage.

Dillard, J. P., \& Shen, L. (2005). On the nature of reactance and its role in persuasive health communication. Communication Monographs, 72, 144-168.

Dobbin, F., \& Kelly, E. L. (2007). How to stop harassment: Professional construction of legal compliance in organizations. American Journal of Sociology, 112, 1203-1243.

Douglass, F. (1857, August 3). 'West India Emancipation' speech at Canandaigua, New York. In P. S. Foner (Ed.), The Life and Writings of Frederick Douglass, vol. 2 (1950).

Dowd, M. (2006). Are men necessary? When sexes collide. New York: The Penguin Group.

Dubner, S. J. (11 October 2012). The Cobra Effect: A New Freakonomics Radio Podcast. Retrieved from http://freakonomics.com/podcast/the-cobra-effect-a-new-freakonomics-radio-podcast/

Eagly, A. H. (1983). Gender and social influence: A social psychological analysis. American Psychologist, 38(9), 971-981.

Edelman, L. B., Uggen, C., \& Erlanger, H. S. (1999). The endogeneity of legal regulation: Grievance procedures as rational myth. American Journal of Sociology, 105, 406-454.

Epstein, C. F., Saute, R., Oglensky, B., \& Gever. M. (1995). Glass ceilings and open doors: Women's advancement in the legal profession. Fordham Law Review, 64, 291-377.

Fisher, A. (2018). Will \#MeToo Spark Backlash Against Women in the Workplace? Fortune. Retrieved from http://fortune.com/2018/11/01/me-too-backlash-women-google/

Fogarty, J. S., \& Youngs, G. A., Jr. (2000). Psychological reactance as a factor in patient noncompliance with medication taking: A field experiment. Journal of Applied Social Psychology, 30(11), 23652391.

Folger, R., \& Baron, R. (1996). Violence and hostility at work: A model of reactions to perceived injustice. In G. VandenBos, \& E. Bulateo (Eds.), Violence on the job (pp. 51-85). Washington, D. C.: American Psychological Association.

Foust-Cummings, H., Dinolfo, S., \& Kohler, J. (2011). Sponsoring Women to Success. Retrieved from https://www.catalyst.org/wp-content/uploads/2019/01/sponsoring_women_to_success.pdf

Friedersdorf, C. (2015, September 11). The Rise of Victimhood Culture. The Atlantic. Retrieved from https:/www.theatlantic.com/politics/archive/2015/09/the-rise-of-victimhood-culture/404794/

Friedman, R. A., Anderson, C. P., Brett, J. M., Olekalns, M., Goates, N., \& Lisco, C. C. (2004). The positive and negative effects of anger on dispute resolution: Evidence from electronically mediated disputes. Journal of Applied Psychology, 89(2), 369-376.

Gates, M. (2019). The moment of lift: How empowering women changes the world. New York: Flatiron Books.

Geddes, D., \& Callister, R. R. (2007). Crossing the line(s): A dual threshold model of anger in organizations. Academy of Management Review, 32(3), 721-746. 
Glomb, T. M. (2002). Workplace anger and aggression: Informing conceptual models with data from specific encounters. Journal of Occupational Health Psychology, 7, 20-36.

Goodwin, R. (2018). Men after \#MeToo: There's a Narrative that Masculinity is Fundamentally Toxic. Retrieved from https://www.theguardian.com/world/2018/mar/09/men-after-metoo-masculinityfundamentally-toxic

Grabitz-Gniech, G. (1971). Some restrictive conditions for the occurrence of psychological reactance. Journal of Personality and Social Psychology, 19(2), 188-196.

Graf, N. (2018). Sexual Harassment at Work in the Era of \#MeToo. Retrieved from http://www. pewsocialtrends.org/2018/04/04/sexual-harassment-at-work-in-the-era-of-metoo/

Grandpre, J. R., Alvaro, E. M., Burgoon, M., Miller, C. H., \& Hall, J. R. (2003). Adolescent reactance and anti-smoking campaigns: A theoretical approach. Health Communication, 15, 349-366.

Haglage, A. (2019). Terry Crews Says Toxic Masculinity Is a 'Cult': Men 'Need Deprogramming.' Retrieved from https://www.yahoo.com/lifestyle/terry-crews-says-toxic-masculinity-cult-menneed-de-programming-150543267.html

Haidt, J. (2017a). We are becoming a culture of victimization. In G. Wiener (Ed.), Microaggressions, safe spaces, and trigger warnings (pp. 30-47). New York: Greenhaven Publishing.

Haidt, J. (2017b). Where Microaggressions Really Come From: A Sociological Account. Retrieved from https://righteousmind.com/where-microaggressions-really-come from/

Heller, J. F., Pallak, M. S., \& Picek, J. M. (1973). The interactive effects of intent and threat on boomerang attitude change. Journal of Personality and Social Psychology, 26(2), 273-279.

Historical List of Women CEOs of the Fortune Lists: 1972-2018. (2018). Catalyst. Retrieved from https://www.catalyst.org/research/women-ceos-of-the-sp-500/

Hsieh, P. (2018). Could \#MeToo Hurt Women's Health Care? Retrieved from https://www.forbes.com/sites/paulhsieh/2018/11/29/could-metoo-hurt-womens-healthcare/\#602580395e85

Jonas, E., Graupmann, V., Niesta Kayser, D., Zanna, M., Traut-Mattausch, E., \& Frey D. (2009). Culture, self, and the emergence of reactance: Is there a 'universal' freedom? Journal of Experimental Social Psychology, 45, 1068-1080.

Kearney, L. K., Rochlen, A. B., \& King, E. B. (2004). Male gender role conflict, sexual harassment tolerance, and the efficacy of a psychoeducative training program. Psychology of Men and Masculinity, 5, 72-82.

Keller, S. N., Wilkinson, T., \& Otjen, A. J. (2010). Unintended effects of a domestic violence campaign. The Journal of Advertising, 39, 53-68.

Kelley, H. H. (1973). The processes of causal attribution. American Psychologist, 28, 107-128.

Kohn, I. (2016). Men Don't Need to be Alive Anymore for the World to Continue. Retrieved from https://therooster.com/blog/could-we-live-world-without-men

Kray, L. J., Thompson, L., \& Galinsky, A. (2001). Battle of the sexes: Gender stereotype confirmation and reactance in negotiations. Journal of Personality and Social Psychology, 80, 942-958.

Krishnan, L., \& Carment, D. W. (1979). Reactions to help: Reciprocity, responsibility and reactance. European Journal of Social Psychology, 9, 435-439

Levine, L. E. (1983). Mine: Self-definition in two-year-old boys. Developmental Psychology, 19, 544549.

Lewis, K. M. (2000). When leaders display emotion: How followers respond to negative emotional expression of male and female leaders. Journal of Organizational Behavior, 21, 221-234.

Maccoby, E. E. (1990). Gender and relationships: A developmental account. American Psychologist, 45(4), 513-520.

Malamuth, N. M., Huppin, M., \& Linz, D. (2018). Sexual assault interventions may be doing more harm than good with high-risk males. Aggression and Violent Behavior, 41, 20-24.

Mann, M. F., \& Hill, T. (1984). Persuasive communications and the boomerang effect: Some limiting conditions to the effectiveness of positive influence attempts. Advances in Consumer Research, $11,66-70$. 
Mann, T., \& Ward, A. (2001). Forbidden fruit: Does thinking about a prohibited food lead to its consumption? International Journal of Eating Disorders, 29, 319-327.

Mazis, M. B., Settle, R. B., \& Leslie, D. C. (1973). Elimination of phosphate detergents and psychological reactance. Journal of Marketing Research, 10, 390-395.

McGee, D. A., \& Hantla, B. F. (2013). The portrayal of fathers in popular media. The Journal of Discipleship and Family Ministry, 3(2), 36-46.

Medinger, F. (2108, August 14). Male Bashing: America's Favorite Pastime. The Baltimore Sun. Retrieved from https://www.baltimoresun.com/news/opinion/oped/bs-ed-op-0815-oppressedmen-20180814-story.html

Miller, C. C. (2017). Unintended Consequences of Sexual Harassment Scandals. New York Times. Retrieved from https://www.nytimes.com/2017/10/09/upshot/as-sexual-harassment-scandalsspook-men-it-can-backfire-for-women.html

Miller, C. H. (2015). Persuasion and psychological reactance: The effects of explicit, high-controlling language. In R. Schulze \& H. Pishwa (Eds), The exercise of power in communication: Devices, reception and reaction (pp. 269-286). Palgrave Macmillan, London.

Miller, C. H., Lane, L. T., Deatrick, L. M., Young, A. M., \& Potts, K. A. (2007). Psychological reactance and promotional health messages: The effects of controlling language, lexical concreteness, and the restoration of freedom. Human Communication Research, 2, 192-240.

Miron, A. M., \& Brehm, J. W. (2006). Reactance theory—40 years later. Zeitschrift Für Sozialpsychologie, 37, 9-18.

Miron-Spektor, E., \& Rafaeli, A. (2009). The effects of anger in the workplace: When, where, and why observing anger enhances or hinders performance. In J. J. Martocchio, \& H. Liao (Eds.), Research in personnel and human resources management, 28, (pp.153-178). Bingley, West Yorkshire, England: Emerald Group Publishing Limited.

Moyer-Gusé, E. (2008). Toward a theory of entertainment persuasion: Explaining the persuasive effects of entertainment-education messages. Communication Theory, 18(3), 407-425.

Moyer-Gusé, E., \& Nabi, R. L. (2010). Explaining the effects of narrative in an entertainment television program: Overcoming resistance to persuasion. Human Communication Research, 36(1), 26-52.

Nemeth, C. (1970). Effects of free versus constrained behavior on attraction between people. Journal of Personality and Social Psychology, 15, 302-311.

Off the Sidelines. (n. d.). Retrieved from https://offthesidelines.org/

Pappas, S. (2019). APA issues first-ever guidelines for practice with men and boys. Monitor on Psychology, 50(1), 34-51.

Parker, K. (2018, December 4). The Inevitable Unintended Consequences of \#MeToo. Washington Post. Retrieved from https://www.washingtonpost.com/opinions/the-inevitable-unintendedconsequences-of-metoo/2018/12/04/9c7e0418-f80e-11e8-8d644e79db33382f_story.html?utm_term $=.7102076 \mathrm{e} 30 \mathrm{ee}$

Pennebaker, J. W., \& Sander, D. Y. (1976). American graffiti: Effects of authority and reactance arousal. Personality and Social Psychology Bulletin, 3, 264-267.

Podolny, J. M., \& Baron, J. N. (1997). Resources and relationships: Social networks and mobility in the workplace. American Sociological Review, 62(5), 673-693.

Poll: Clinton's Approval Ratings Up in Wake of Impeachment. (1998, December 20). Retrieved from http://www.cnn.com/ALLPOLITICS/stories/1998/12/20/impeachment.poll/

Repko, M. (2019, May 5). A call to eliminate barriers for women. Dallas Morning News, (pp. 6E).

Rhoads, K. V. L., \& Cialdini, R. B. (2002). The business of influence: Principles that lead to success in commercial settings. In J. P. Dillard \& M. Pfau (Eds.), The persuasion handbook (pp. 513-542). Thousand Oaks, CA: Sage

Robb, L. A., \& Doverspike, D. (2001). Self-reported proclivity to harass as a moderator of the effectiveness of sexual harassment-prevention training. Psychological Reports, 88, 85-88.

Robertson, T. S., \& Rossiter, J. R. (1974). Children and commercial persuasion: An attribution theory analysis. Journal of Consumer Research, 1(1), 13-20. 
Roehling, M. V., \& Huang, J. (2018). Sexual harassment training effectiveness: An interdisciplinary review and call for research. Journal of Organizational Behavior, 39, 134-150.

Rosenberg, B. D., \& Siegel, J. T. (2018). A 50-year review of psychological reactance theory: Do not read this article. Motivation Science, 4(4), 281-300.

Rosin, H. (2012). End of men and the rise of women. New York: Penguin Group.

Sawaoka, T., \& Monin, B. (2018). The paradox of viral outrage. Psychological Science, 29(10), 16651678.

Schnall, M. (2017). 2018 Will Be the Year of Women. Retrieved from https:/www.cnn.com/2017/12/14/opinions/2018-will-be-the-year-of-women-schnall/index.html

Schultz, V. (2003). The sanitized workplace. Yale Law Journal, 112(8), 2061-2194.

Shen, L. J. (2010a). Mitigating psychological reactance: The role of message-induced empathy in persuasion. Human Communication Research, 36, 397-422.

Shen, L. J. (2010b). On a scale of state empathy during message processing. Western Journal of Communication, 74, 504-524.

Shen, L. J. (2011). The effectiveness of fear- vs. empathy-arousing anti-smoking PSAs. Health Communication, 26, 404-415.

Shen, L. J., \& Coles, V. B. (2015). Fear and psychological reactance: Between- Versus WithinIndividuals Perspectives. Zeitschrift für Psychologie, 223(4), 225-235.

Sittenthaler, S., Jonas, E., \& Traut-Mattausch, E. (2016). Explaining self and vicarious reactance: A process model approach. Personality and Social Psychology Bulletin, 42(4), 458-470.

Smith, K. (2018). A Male Backlash against \#MeToo Is Brewing. New York Post. Retrieved from https://nypost.com/2018/02/03/a-male-backlash-against-metoo-is-brewing/

Society for Human Resource Management. (2018). Harassment-Free Workplace Series: The Executive View. Retrieved from https://shrm.org/hr-today/trends-and-forecasting/research-andsurveys/Pages/Harassment-Free-Series-ExecutiveView.aspx?_ga=2.127641485.1047288393.1540137765-1104436705.1479910731

Soklaridis, S., Zahn, C., Kuper, A., Gillis, D., Taylor, V. H., \& Whitehead, C. (2018). Men's fear of mentoring in the \#MeToo era-What's at stake for academic medicine? New England Journal of Medicine, 379, 2270-2274.

Steindl, C., Jonas, E., Sittenthaler, S., Traut-Mattausch, E., \& Greenberg, J. (2015). Understanding psychological reactance: New developments and findings. Zeitschrift für Psychologie, 223(4), 205-214.

Synnott, A. (2010). Why Some People Have Issues with Men: Misandry. Retrieved from https://www.psychologytoday.com/us/blog/rethinking-men/201010/why-some-people-haveissues-men-misandry

Tan, G., \& Porzecanski, K. (2018). Wall Street Rule for the \#MeToo Era: Avoid Women at All Cost. Retrieved from https://www.bloomberg.com/news/articles/2018-12-03/a-wall-street-rule-for-themetoo-era-avoid-women-at-all-cost

Thompson, S. (2018). \#MeToo Is Having Unexpected Consequences for Working Women. Retrieved from https://www.weforum.org/agenda/2018/03/metoo-campaign-women-isolated-at-work/

Tinkler, J. E. (2008). People are too quick to take offense: The competing effects of knowledge and beliefs on definitions of sexual harassment. Law \& Social Inquiry, 33, 417-445.

Tinkler, J. E. (2012). Resisting the enforcement of sexual harassment. Law \& Social Inquiry, 37, 1-24.

Trafimov, D., Triandis, H. C., \& Goto, G. (1991). Some tests of the distinction between the private self and the collective self. Journal of Personality and Social Psychology, 60(5), 649-655.

Traister, R. (2018). Good and mad: The revolutionary power of women's anger. New York: Simon \& Schuster.

Tudor, T. (2015). Rabble Rouser: Men Have Made a Mess of Society. Retrieved from https://www.courierpostonline.com/story/opinion/readers/2015/03/25/rabble-rouser-men- mademess-society/70455508/ 
Turner, J. C., Hogg, M. A., Oakes, P. J., Reicher, S. D., \& Wetherell, M. S. (1987). Rediscovering the social group: A self-categorization theory. Cambridge, MA: Basil Blackwell.

University of Toronto Faculty of Medicine. (2018). Men's Fear of Mentoring in the \#MeToo Era. Retrieved from https://medicine.utoronto.ca/news/men-s-fear-mentoring-metoo-era

Vansteenkiste, M., Lens, W., \& Deci, E. L. (2006). Intrinsic versus extrinsic goal contents in selfdetermination theory: Another look at the quality of academic motivation. Educational Psychologist, 41(1), 19-31.

Wayne, T. (2015, November 15). The Microcomplaint: Nothing Too Small to Whine About. New York Times. Retrieved from https://www.nytimes.com/2015/11/15/fashion/the-microcomplaintnothing-too-small-to-whine-about.html

Weiner, J., \& Brehm, J. W. (1966). Buying behavior as a function of verbal and monetary inducements. In J. W. Brehm (Ed.), A theory of psychological reactance (pp. 82-90). New York: Academic Press.

Wicklund, R. A. (1974). Freedom and reactance. Potomac, MD: Erlbaum.

Witte, K. (1992). Putting the fear back into fear appeals: The extended parallel process model. Communication Monographs, 59, 329-349.

Wolburg, J. M. (2006). College students' responses to antismoking messages: Denial, defiance, and other boomerang effects. Journal of Consumer Affairs, 40, 294-323.

Woller, K. M. P., Buboltz, W. C., \& Loveland, J. M. (2007). Psychological reactance: Examination across age, ethnicity, and gender. The American Journal of Psychology, 120(1), 15-24.

Worchel, S. (2004). Some unique characteristics of ethnic conflict and their implications for managing the conflict. In Y.-T. Lee, C. McCauley, F. Moghaddam, \& S. Worchel (Eds.), Psychological dimensions to war and peace. The psychology of ethnic and cultural conflict (pp. 289-306). Westport, CT: Praeger Publishers/Greenwood Publishing Group.

Worchel, S., Andreoli, V. A., \& Archer, R. (1976). When is a favor a threat to freedom: The effects of attribution and importance of freedom on reciprocity. Journal of Personality, 44, 294-310.

Worchel, S., \& Brehm, J. W. (1970). Effects of threats to attitudinal freedom as a function of agreement with the communicator. Journal of Personality and Social Psychology, 14, 18-22.

Zobel-Nolan, A., \& Hollander, N. (1994). 101 reasons why a cat is better than a man. NY: Adams Media Books. 